GRASAS Y ACEITES 66 (3)

July-September 2015, e090

ISSN-L: 0017-3495

doi: http://dx.doi.org/10.3989/gya.0944142

\title{
Physicochemical properties, phenolic acids and volatile compounds of oil extracted from dry alhydwan (Boerhavia elegana Choisy) seeds
}

\author{
A. Al-Farga ${ }^{\mathrm{a}, \mathrm{b}}$, H. Zhang ${ }^{\mathrm{a}, \bowtie}$, A. Siddeeg ${ }^{\mathrm{a}, \mathrm{c}}$, M.V.M. Chamba ${ }^{\mathrm{a}, \mathrm{d}}$ and Q.A. Nabil ${ }^{\mathrm{a}}$ \\ ${ }^{a}$ State key Laboratory of Food Science and Technology, School of Food Science and Technology, \\ Jiangnan University, 1800 Lihu Avenue, Wuxi 214122, P.R. China \\ ${ }^{b}$ Department of Food Science, Faculty of Agriculture, Ibb University, Ibb, Yemen \\ ${ }^{\mathrm{c}}$ Department of Food Science and Technology, Faculty of Engineering and Technology, University of Gezira, Wad Medani, Sudan \\ ${ }^{\mathrm{d}}$ Department of Human Ecology, Domasi College of Education, P.O. Box 49, Domasi, Zomba, Malawi \\ ${ }^{\square}$ Corresponding author: zhanghui@jiangnan.edu.cn
}

Submitted: 11 September 2014; Accepted: 23 February 2015

\begin{abstract}
SUMMARY: In this study, the chemical composition, physicochemical properties, phenolic acids and volatile compounds of alhydwan (Boerhavia elegana Choisy) seed oil were evaluated. The crude oil content was $11.49 \%$, ash $6.88 \%$, moisture $6.12 \%$, protein content $14.60 \%$, total carbohydrate $24.77 \%$ and fiber $36.13 \%$. The oil contain a high quantity of unsaturated fatty acids $\left(74.63 \mathrm{mg} \cdot 100 \mathrm{~g}^{-1}\right)$ with oleic $(\mathrm{C} 18: 1)(57.77 \%)$, palmitic $(\mathrm{C} 16: 0)$ $(18.65 \%)$ and linoleic (C18:2) (12.88\%) acids as the most abundant. The relative density was 0.88 and the iodine value 105.59. The color analysis showed a value of $28.33 \mathrm{Y}+1.43 \mathrm{R}$. The oil also had a high relative oxidative stability. The tocol composition showed that $\alpha$-tocotrienol, $\gamma$-tocopherol and $\gamma$-tocotrienol were in a higher concentration than the rest. Seven phenolic acids (caffeic, vanillic, galic, $p$-coumaric, ascorbic, cinnamic and ferulic) were detected, with ascorbic acid as the predominant one $\left(5.44 \mathrm{mg} \cdot 100 \mathrm{~g}^{-1}\right)$. In relation to the volatile composition, 48 compounds were found with Z-10-Pentadecen-1-ol (56.73\%); Hexadecenoic acid, Z-11- (18.52\%); 9,12-Octadecadienoic acid (Z,Z)- (3.93\%) and 9,12-Octadecadienoic acid (Z,Z)-, 2-hydroxy-1-(hydroxymethyl) ethyl ester $(3.04 \%)$ as the most abundant. These findings demonstrated the potential of alhydwan seeds to be used as a good source of quality edible oil.
\end{abstract}

KEYWORDS: Alhydwan; Boerhavia elegana Choisy; Novel food; Phenolic acids; Physicochemical properties; Volatile compounds

RESUMEN: Propiedades físico-químicas, ácidos fenólicos y compuestos volátiles del aceite extraído de semillas de alhydwan (Boerhavia elegana Choisy). En este estudio se ha determinado la composición química, las propiedades físico-químicas, ácidos fenólicos y compuestos volátiles de aceites de semillas de alhydwan (Boerhavia elegana Choisy). Las semillas contenían un $11.49 \%$ de aceite, $6.88 \%$ de cenizas, $6,12 \%$ de humedad, $14.60 \%$ de proteínas, $24.77 \%$ de carbohidratos totales y $36.13 \%$ de fibra. El aceite contiene $74,63 \mathrm{mg} \cdot 100 \mathrm{~g}^{-1}$ de ácidos grasos insaturados, con oleico (C18: 1) (57,77\%), palmítico (C16: 0) (18,65\%) y linoleico (C18: 2) (12,88\%) como los más abundantes. La densidad relativa fue de 0,88 y el índice de yodo de 105,59. El análisis del color mostró un valor de $28.33 \mathrm{Y}+1,43 \mathrm{R}$. El aceite también mostro tener una alta estabilidad oxidativa relativa. La determinación de la composición de tocols mostró que $\alpha$-tocotrienol, $\gamma$-tocoferol y $\gamma$-tocotrienol están presentes en mayor concentración que el resto. Se detectaron siete ácidos fenólicos (cafeico, vaníllico, galico, p-cumárico, ascórbico, cinámico y ferúlico), siendo el ácido ascórbico el mayoritario $\left(5,44 \mathrm{mg} \cdot 100 \mathrm{~g}^{-1}\right)$. En la determinación de volátiles, se encontraron 48 componentes, con Z-10-Pentadecen-1-ol (56,73\%); ácido hexadecenoico, Z-11- (18,52\%); ácido 9,12-octadecadienoico (Z, Z) - (3,93\%) y ácido 9,12-octadecadienoico (Z, Z) -, éster 2-hidroxi-1- (hidroximetil) etil (3,04\%) como mayoritarios. Estos resultados demostraron que las semillas de alhydwan tiene un gran potencial para ser utilizadas como una buena fuente de aceite comestible de calidad. 
PALABRAS CLAVE: Ácidos fenólicos; Alhydwan; Boerhavia elegana Choisy; Compuestos volátiles; Nuevo alimento; Propiedades físico-químicas

Citation/Cómo citar este artículo: Al-Farga A, Zhang H, Siddeeg A, Chamba MVM, Nabil QA. 2015. Physicochemical properties, phenolic acids and volatile compounds of oil extracted from dry alhydwan (Boerhavia elegana Choisy) seeds. Grasas Aceites 66 (3): e090. doi: http://dx.doi.org/10.3989/gya.0944142.

Copyright: (C) 2015 CSIC. This is an open-access article distributed under the terms of the Creative Commons Attribution-Non Commercial (by-nc) Spain 3.0 Licence.

\section{INTRODUCTION}

Due to the ever-increasing demand for and price of edible oils, a number of explorations are being made to discover more edible oils, more especially those extracted from plant sources (Sbih et al., 2013). The global supply available from conventional animal fat and vegetable oils is not sufficient to meet all the energy requirements without compromising the demand for food. Much attention however, is put on plant seed sources that have been proven to have healthy and nutritional benefits to consumers in one way or another (Su et al., 2014). In recent years there has been an increased important exploitation of promising plant species as a source of dietary or specialty oils (Jelassi et al., 2014). Several of these plants contain considerable quantities of oils, desirable fatty acids and/or a high proportion of nutritionally, medicinally or industrially important materials (Bowen and Clandinin, 2005). Nevertheless, with regards to the ever-growing world population, the demand for high-quality seed oils continues to grow. In order to meet this demand, there is a need to increase the production of the major oil crops and to diversify the sources through increasing and improving the production of minor oil crops (Mulatu et al., 2011). Vegetable oils are utilized in many foods and many other industrial processes. Of great importance are those with higher relative content of minor lipid components for human health (Jelassi et al., 2014). The world consumption is dominated by palm, soybean, rapeseed and sunflower oils with 38.1, 35.7, 17.8 and 18.2 million tones consumed per year, respectively (American Soybean Association, 2007) with world interest still on the recovery and exploitation of oils from more natural plant resources (Jelassi et al., 2014). Alhydwan (Boerhavia elegana Choisy) is one of the edible herbaceous plants, a type of Boerhavia that belongs to the Nynctaginaceae family, commonly available in South Yemen (Boulous, 1988). Boerhavia is a genus of 40 species, almost all of which are widely distributed in tropical and sub-tropical areas of Asia, Africa, America and Australia (Chaudhary et al., 2011). Alhydwan is cultivated only in Yemen and is not well known even in its neighboring countries. It has a long history of uses by indigenous and tribal people there in the traditional cuisine of as one of the staple ingredients in the manufacture of porridge, desserts and savory products. It is also eaten as a supplement mixed in bread and cakes, and is characterized by good flavor (Al-Farga et al., 2014). To our knowledge so far, there is no scientific report on physiochemical properties, chemical composition, phenolic acids and volatile compounds of oil extracted from the alhydwan seeds. The present study therefore, aimed at examining these particular aspects. The knowledge of these properties may lead to the innovative use of alhydwan seed oil for food and other industrial purposes.

\section{MATERIALS AND METHODS}

\subsection{Material and chemicals}

Dried alhydwan seeds were brought from a local farm in Wad Hadramout City, Yemen in June of 2014 after harvesting, and transported to the Functional Ingredients and Healthy Foods Laboratory of Jiangnan University, Wuxi city, China. Seeds were milled using a laboratory scale hammer mill (Tianjin Taisite Instrument Co., Ltd., Tianjin, China). Flour was then screened ( 80 mesh), packed in polyethylene bags, and stored in a refrigerator at $5{ }^{\circ} \mathrm{C}$ until use. Standard tocopherols were purchased from Sigma Aldrich, Shanghai, China. All other chemicals were of analytical grade.

\subsection{Oil extraction}

The seeds ( $100 \mathrm{~g})$ were mixed with $1 \mathrm{~L}$ of $\mathrm{n}$-hexane using a shaker (IKA ${ }^{\circledR}$ RW 20 digital, UK-plug) at a rate of $440 \mathrm{rpm}$ for $4 \mathrm{~h}$. The mixture was then centrifuged for $20 \mathrm{~min}$ at $4{ }^{\circ} \mathrm{C}$. The mixture was then filtered and the supernatant was recovered. The extraction process was repeated. The oil trapped in the supernatant was then recovered by evaporating off the solvent using a rotary evaporator (Model N-1, Eyela; Tokyo Rikakikal, Japan). The remaining solvent was removed under a laboratory fume hood for $30 \mathrm{~min}$ at $37^{\circ} \mathrm{C}$. The extracted oil was drained under a nitrogen stream and was then stored in a refrigerator at $4{ }^{\circ} \mathrm{C}$ for further analysis.

\subsection{Proximate composition analysis of alhydwan seeds}

The following analyses were carried out: Nitrogen contents were determined using a microKjeldahl method. Moisture content was determined 
by oven-drying at $60{ }^{\circ} \mathrm{C}$ to constant weight. Crude lipids were estimated by employing the Soxhlet apparatus method using $\mathrm{n}$-hexane as solvent. The standard methods of The Association of Official Analytical Chemists (AOAC, 2000) were employed for the estimation of the proximate composition of seed flour. Crude fiber contents were estimated as outlined in the AOAC Method 962.09 (AOAC, 2000). Ash content was determined by ashing the sample at $550{ }^{\circ} \mathrm{C}$ to constant weight. Iron content was determined using a UV-Visible spectrophotometer (TECHCOM Co., Shanghai, China) at $480 \mathrm{~nm}$ (AOAC, 1995). Magnesium was determined according to the method described by Ranganna (1986). The blue color that developed was read at $650 \mathrm{~nm}$ in a UV-Visible spectrophotometer and expressed as magnesium $\mathrm{mg} \cdot 100 \mathrm{~g}^{-1}$ meal. Other minerals were determined by atomic absorption spectroscopy (Shimadzu AA 6701F, Atomic Absorption Flame Emission Spectrophotometer equipped with a hollow cathode lamp).

\subsection{Total energy (Caloric value)}

Energy was calculated according to the method of (Osborne, D.R. and Voogt, P. 1978), using the Atwater factor. $1 \mathrm{~g}$ of fat provides (9 K calories), $1 \mathrm{~g}$ of protein provides ( $4 \mathrm{~K}$ calories) and $1 \mathrm{~g}$ of carbohydrates provides ( $4 \mathrm{~K}$ calories).

\subsection{Chemical analysis of the oil}

The American Oil Chemist's Society (1997) methods were used for the estimation of free fatty acids (method Ca 5a-4), peroxide value (method Cd 8-53), saponification value (method Cd 3-25), unsaponifiable matter (method Ca 6a-40), and specific gravity (using a $10 \mathrm{~mL}$ pycnometer at $25^{\circ} \mathrm{C}$ ). The refractive index was determined using an Abbe refractometer at $25{ }^{\circ} \mathrm{C}$. The iodine value was calculated following the procedures of Kyriakidis and Katsiloulis (2000). Specific absorption values $\mathrm{k}_{232}$ and $\mathrm{k}_{270}$ were estimated using a UV spectrophotometer.

\subsection{Determination of the oil's fatty acid composition}

Fatty acid methyl esters (FAME) were prepared by methylation of the total lipids according to the method described by Azhari et al. (2014). One $\mu \mathrm{L}$ of FAME sample was analyzed by gas chromatography (GC) (Shimadzu GC-2010, Series PEG30 M, Japan) equipped with a flame ionization detector. GC separation was conducted on a capillary column (PEG30 M; $30 \mathrm{~m} \times 0.32 \mathrm{~mm} \times 0.50 \mu \mathrm{m})$. The carrier gas was nitrogen and the column flow rate was $0.8 \mathrm{~mL} \cdot \mathrm{min}^{-1}$. The chromatographic analysis was done at $190{ }^{\circ} \mathrm{C}$ oven temperature for $1 \mathrm{~min}$ and then increased to $230^{\circ} \mathrm{C}$ at a rate of $3{ }^{\circ} \mathrm{C} \cdot \mathrm{min}^{-1}$ and maintained at $230^{\circ} \mathrm{C}$ for $10 \mathrm{~min}$. The injector and detector temperatures were 240 and $250{ }^{\circ} \mathrm{C}$, respectively. The peaks were estimated on the chromatogram according to retention time from analyzed standard samples. Finally, fatty acid contents were calculated as percentages (\%).

\subsection{Color parameters}

The color of the alhydwan oil was measured with a Hunter Lab digital colorimeter (TC-PIIG system, Beijing Optical Instrument Co. Ltd., Beijing, China) as $\mathrm{R}$ Value on the red slide, $\mathrm{Y}$ value on the yellow slide and the values were recorded. A cylindrical plastic dish $(58 \mathrm{~mm}$ in diameter and $15 \mathrm{~mm}$ in depth) containing the same content of sample was placed at the light port $(50 \mathrm{~mm}$ in diameter).

\subsection{Oxidative stability determination}

The oxidative stability was determined with the 743 Rancimat apparatus (Metrohm Co., Basel, Switzerland). The oxidative-induction time (OIT) was determined using $3.5 \mathrm{~g}$ of oil. The temperature was set at $100{ }^{\circ} \mathrm{C}$, and the purified air flow at a rate of $10 \mathrm{~L} \cdot \mathrm{h}^{-1}$. During the oxidation process, volatile acids were formed in the distilled water where the conductivity was measured. The induction period was defined as the time necessary to reach the inflection point of the conductivity curve.

\subsection{Tocol composition}

The tocol composition was determined according to norm ISO 9936 by HPLC (Agilent 1100, CA, USA), consisting of a G1354 quaternary pump, a G1313A standard auto sampler, a G1321A fluorescence detector set at $(\lambda$ excitation $=295 \mathrm{~nm}$, and $\lambda$ emission $=330 \mathrm{~nm}$ ) and chemstation software. The seed oil $0.5 \mathrm{~g}$ was diluted with $5 \mathrm{~mL}$-hexane and $5 \mu \mathrm{L}$ samples were automatically injected into a normal phase column (Pinnacle II silica) $(150 \mathrm{~mm} \times 3.2 \mathrm{~mm} \times 3 \mu \mathrm{m})$ with hexane/isopropanol $(99.5 / 0.5, \mathrm{v} / \mathrm{v})$ as a mobile phase. The system was operated isocratically at a flow rate of $0.5 \mathrm{~mL} \cdot \mathrm{min}^{-1}$. The separations were carried out at $30{ }^{\circ} \mathrm{C}$. The mixed tocopherol standards in a hexane solution $\left(2 \mathrm{mg} \cdot \mathrm{mL}^{-1}\right)$ were prepared from the standard compounds: $\alpha-, \beta-, \gamma-$, and the $\delta$-tocopherols (Sigma Aldrich, Shanghai, China. The tocotrienol peaks of B. elegana Choisy seed oil were identified by comparison with tocol chromatograms of coconut oil and palm oil obtained under similar analytical conditions.

\subsection{Determination of sterols}

The sterol components of alhydwan seed oil were determined by derivatization with $\mathrm{N}$-methyl$\mathrm{N}$-trimethyl-silyl-heptafluorbutyramid as silylation agent. The assignments of the peaks were made using 
the retention times of the individual sterols and calculation of the relative retention times in relation to betulin according to internal standard (ISO/FIDS, 1999). In brief, $250 \mathrm{mg}$ of oil were saponified with a solution of ethanolic potassium hydroxide by boiling under reflux. The unsaponifiable matter was extracted by solid-phase extraction on an aluminum oxide column on which fatty acid anions were retained and sterols passed through. The sterol fraction from the unsaponifiable matter was separated by thin-layer chromatography (TLC) on $20 \times 20 \mathrm{~cm}$ silica gel, $0.25 \mathrm{~mm}$ layer thickness using hexane/diethyl ether 1:1 (v/v) as developing solvent was extracted again from the TLC substrate. The sterol fraction was detected by gas liquid chromatography using an internal standard (betulin). Unclear cases were detected by GC mass only lastly, other parameters were: hydrogen, which was the carrier gas; split ratio, 1:20; injection and detection temperature were established at $320^{\circ} \mathrm{C}$; oven temperature was programmed between $245-260^{\circ} \mathrm{C}$ at $5^{\circ} \mathrm{C} \cdot \mathrm{min}^{-1}$.

\subsection{Identification and quantification of phenolic acids by HPLC-MS/MS}

The HPLC-MS were performed with an Agilent 1100 LC system consisting of a degasser, a binary pump, an auto sampler, and a column heater (chromatographic separation, a Knauer $\mathrm{C} 18$ column $(250 \mathrm{~mm} \times 4.6 \mathrm{~mm}, 5 \mu \mathrm{m})$. CHEMCAD 6.3, chemical process simulation software designed by chemstation, Inc, was used to obtain data acquisition and mass spectrometric evaluation. The column outlet was coupled to an Agilent MSD Ion Trap XCT mass spectrometer equipped with an ESI ion source. The column set at $40{ }^{\circ} \mathrm{C}$ was first held at $90 \%$ solvent $\mathrm{A}(1 \%$ acetic acid in water) and $10 \%$ solvent B ( $1 \%$ acetic acid in methanol), followed by a step gradient from $10 \% \mathrm{~B}$ to $20 \% \mathrm{~B}$ in $4 \mathrm{~min}$, and a second step gradient from $20 \%$ B to $100 \%$ B in 20 min. Thereafter, it was held for 6 minutes with $100 \%$ B. Finally, the elution was obtained from $100 \%$ B to $20 \% \mathrm{~B}$ for $6 \mathrm{~min}$. The flow rate was $400 \mu \mathrm{L} \cdot \mathrm{min}^{-1}$ and the injection volume was $10 \mu \mathrm{L}$ of the mixture that contains $900 \mu \mathrm{L}$ of ethyl acetate and $100 \mu \mathrm{L}$ of alhydwan seeds oil. The following parameters were used in all stages of the experiment MS, that is, for electro spray ionization with negative ion polarity: the drying gas flow at $10 \mathrm{~L} \cdot \mathrm{min}^{-1}$, the nebulizer pressure at $40 \mathrm{psi}$, the drying temperature at $350{ }^{\circ} \mathrm{C}$ and the capillary voltage was set at $1.6 \mathrm{kV}$. The scan speed was $26,000 \mathrm{mZ}^{-1} \mathrm{~s}^{-1}$ (Ultra Scan Mode), the fragmentation time was $30 \mathrm{~ms}$, whereas the maximum accumulation time was $50 \mathrm{~ms}$. The phenolic compounds were identified using a combination of high performance liquid chromatography (HPLC, Agilent 1100) for diode array detection and liquid chromatography with electro spray ionization mass spectrometry (ESI-LC-MS). Ultraviolet (UV) spectra and mass spectra were compared to the spectra of authentic standards available.

\subsection{Determination of volatile compounds}

The volatile compounds were separated on a CP-Sil-8CB (Varian, Walnut Creek, CA, USA) fused silica capillary column $(30 \mathrm{~m}$ length, $0.25 \mathrm{~mm}$, id, and $0.25 \mu \mathrm{m}$ film thicknesses) using a Varian model 3800 gas chromatography. The splitless mode injector was maintained at $220{ }^{\circ} \mathrm{C}$ and the flame ionization detector (FID) at $250{ }^{\circ} \mathrm{C}$, with a capillary column DB WAX $(30 \mathrm{~m} \times 0.25 \mu \mathrm{m}, \mathrm{J}$ and W Scientific, Folsom, CA, USA). The oven temperature was set at $40{ }^{\circ} \mathrm{C}$, held for $3 \mathrm{~min}$, ramped up to $100{ }^{\circ} \mathrm{C}$ at the rate of $6{ }^{\circ} \mathrm{C} \cdot \mathrm{min}^{-1}$ and then to $230^{\circ} \mathrm{C}$ at $10^{\circ} \mathrm{C} \cdot \mathrm{min}^{-1}$. The constant column flow was $0.9 \mathrm{~mL} \cdot \mathrm{min}^{-1}$. Mass spectra was obtained in the Electron Impact (EI+) mode with an energy voltage of $70 \mathrm{eV}$; the mass range was 33 to $450 \mathrm{~m} / \mathrm{z}$. volatile compound identification were conducted by matching their mass spectra of standard compounds found in the wily $130 \mathrm{~K}$ and national institute of standards and technology (NIST) 98 library of MS spectra and based on their retention indices.

\section{RESULTS AND DISCUSSION}

\subsection{Chemical analysis of powdered alhydwan seeds}

The chemical composition of alhydwan seeds is shown in Table 1. Fiber, fat, protein, carbohydrates, and ash were $36.13 \%, 11.49 \%, 14.60 \%, 24.77 \%$ and $6.88 \%$ on dry weight, respectively, and the moisture content was $6.12 \%$. The high level of fiber makes alhydwan seeds convenient for food industry applications, and they could be a source of dietary fiber for animals. Since, alhydwan seed contains a good level of oil it is considered to be a good source for application in functional foods. The seeds are good sources for lipids, which contain fatty acids that play a very important role in the human body (Saidu and Jideobi, 2009). They facilitate the absorption of fatsoluble vitamins such as vitamins A and E (Osborne and Voogt, 1978). The variations in the oil content can be related to differences in plant species, climate cultivation, isolation method used and ripening level (Nyam et al., 2009). Alhydwan seeds were also found to contain high levels of minerals (Table 1). Calcium was the most abundant element $\left(655 \mathrm{mg} \cdot 100 \mathrm{~g}^{-1}\right)$, whereas copper was found at the lowest level.

\subsection{Total Energy (Caloric Value)}

The total energy content of the alhydwan seed is recorded in Table 1, where the calorific value has been calculated for fat, carbohydrates, and protein at $1.03,0.99$ and $0.58 \mathrm{kcal} \cdot \mathrm{g}^{-1}$, respectively, with fat providing the highest amount of energy. From these 
TABLE 1. Proximate composition and mineral contents of alhydwan B. Elegana Choisy (\% w/w on dry basis $)^{\mathrm{a}}$

\begin{tabular}{lrc}
\hline Chemical Components & & Kcal·g $^{-1}$ \\
\hline Proximate composition (\%) & & \\
Moisture & $6.12 \pm 0.11$ & - \\
Crude protein & $14.60 \pm 0.54$ & 0.58 \\
Carbohydrates & $24.77 \pm 0.35$ & 0.99 \\
Crude fat & $11.49 \pm 0.81$ & 1.03 \\
Fiber & $36.13 \pm 0.33$ & - \\
Ash & $6.88 \pm 0.16$ & - \\
Minerals content (mg·100 g & \\
Zinc $(\mathrm{Zn})$ & & \\
Iron (Fe) & $1.72 \pm 1.44$ & \\
Copper (Cu) & $3.83 \pm 1.52$ & \\
Manganese (Mn) & $0.44 \pm 0.62$ & \\
Potassium (K) & $0.73 \pm 0.72$ & \\
Sodium (Na) & $595.00 \pm 1.52$ & \\
Magnesium (Mg) & $26.15 \pm 0.71$ & \\
Calcium (Ca) & $109.50 \pm 0.54$ & \\
\hline
\end{tabular}

${ }^{a}$ All values given are means of three determinations means \pm standard deviation.

data, alhydwan seeds can be considered good sources of calories. It is well known that a calorie is a measurement of energy, the energy can be used immediately or stored for later use, and foods have calories. That is, foods supply the body with energy, which is released when foods are broken down during digestion. Thus, energy enables the cells to carry out all of their functions, including building protein and others substances needed by the body (Duyff and Ada, 2011).

\subsection{Chemical analysis of the oil}

Table 2 presents the chemical properties of $B$. elegana Choisy seed oil. The oil was in liquid state at room temperature, an indication of polyunsatulated fatty acids. The iodine value was relatively high compared to other oils suggesting that the seed oil has good edible oil quality (Eromosele et al., 1997). The values of peroxide $\left(3.35 \mathrm{meq} \mathrm{O}_{2} \cdot \mathrm{kg}^{-1}\right.$ oil), free fatty acid composition (1.44\%) and $p$-Anisidine (3.11) were very low indicating that the oil can be stored for a long period without deterioration (Ojeh, 1981). The high saponification value determined, $182.88 \mathrm{mg}$ of $\mathrm{KOH} \cdot \mathrm{g}^{-1}$ of oil, suggested a high content of low molecular weight triacylglycerols (Nehdi et al., 2010). It was close to that of raspberry seed oil (Oomah et al., 2000). Iodine value is the measurement of the degree of unsaturation of the oil. The iodine value for Alhydwan seed oil was 105.59; this result was found similar to the found by Roselle and Bittermelon (Nyam et al., 2009). The iodine values of these seed
TABLE 2. Physicochemical properties of alhydwan seed oil

\begin{tabular}{lc}
\hline Parameters & Values \\
\hline Physical state at room temperature & Liquid \\
Free fatty acids (oleic acid \%) & $1.44 \pm 0.06$ \\
Iodine value & 105.59 \\
Peroxide value (meq $\mathrm{O}_{2} \cdot \mathrm{kg}^{-1}$ oil) & $3.35 \pm 0.20$ \\
$\mathrm{k}_{232}$ & $3.03 \pm 0.18$ \\
$\mathrm{k}_{270}$ & $1.51 \pm 0.08$ \\
Color & $28.33 \mathrm{Y}+1.43 \mathrm{R}$ \\
Index of refraction $\left(25^{\circ} \mathrm{C}\right)$ & $1.43 \pm 0.06$ \\
Relative density $\left(25^{\circ} \mathrm{C}\right)$ & $0.88 \pm 0.03$ \\
Unsaponifiable matter $(\%)$ & $1.19 \pm 0.11$ \\
Saponification value $\left(\mathrm{mg} \mathrm{KOH} \cdot \mathrm{g}^{-1}\right.$ oil) & $182.88 \pm 0.11$ \\
$p$-Anisidine value & $3.11 \pm 0.17$ \\
Oil stability index $(\mathrm{h})$ & $16.82 \pm 0.09$ \\
\hline
\end{tabular}

Values are means $\pm \mathrm{SD}$ of three determinations. $R$ value on the red slide, $Y$ value on the yellow slide. Iodine value was calculated following Kyriakidis and Katsiloulis (2000).

oils are situated inside the interval range of the value as mentioned by Tan et al. (2002).

\subsection{Fatty acid composition}

The fatty acid composition of alhydwan seed oil is recorded in Table 3. Among the current nine fatty acids, five were unsaturated. The most abundant fatty acids were oleic (C18:1) (57.77\%), palmitic (C16:0) $(18.65 \%)$ and linoleic (C18:2) (12.88\%). Therefore, alhydwan seed oil was not similar to sunflower oil, which contains a lower content of linoleic acid, but a higher content of oleic acid (El-Mallah et al., 1999). It is worth mentioning that the high content of oleic acid makes alhydwan seed oil a potential source of oil for patients with arteriosclerosis and essential hypertension. This means that the consumption of alhydwan seed oil may offer health benefits (Oomah et al., 2000), making it a potential alternative natural oil to replace or combine with other edible oils.

\subsection{Oxidative stability}

The results from the Rancimat test are presented in Table 2. The oxidative stability of the alhydwan oil was relatively high $(16.82 \mathrm{~h})$. This value may be due to the high composition of oleic acid, which has only one double bond in the chain and the corresponding ester undergoes oxidation at a slower rate than the polyunsaturated esters (da Silva et al., 2014). A linear regression on the basis of the ratio of linoleic acid and the contents of tocopherols and phenols in virgin olive oil and a good correlation with the oxidative stability measured by Rancimat have been reported (Aparicio et al., 1999). 
TABLE 3. Fatty acid composition of alhydwan $\left(\mathrm{g} \cdot 100 \mathrm{~g}^{-1} \text { total fatty acid }\right)^{\mathrm{a}}$

\begin{tabular}{lc}
\hline Fatty acid & Composition \\
\hline$\sum$ SFA & 22.2 \\
Myristic acid (C14:0) & $0.2 \pm 0.01$ \\
Palmitic acid (C16:0) & $18.6 \pm 0.03$ \\
Stearic acid (C18:0) & $2.1 \pm 0.06$ \\
Arachidic acid (C20:0) & $1.3 \pm 0.04$ \\
$\sum$ UFA & 74.6 \\
Palmitoleic acid (C16:1) & $0.16 \pm 0.02$ \\
Oleic acid (C18:1) & $57.8 \pm 0.4$ \\
Linoleic acid (C18:2) & $12.9 \pm 0.09$ \\
Linolenic acid (C18:3) & $2.3 \pm 0.05$ \\
Eicosenoic acid (C20:1) & $1.5 \pm 0.03$ \\
$\sum$ MUFA & 59.4 \\
$\sum$ PUFA & 15.2 \\
Ratio SFA/UFA & 3.9 \\
\hline
\end{tabular}

${ }^{a}$ All values given are means of three determinations means 土standard deviation.

SFA- saturated fatty acids; MUFA- monounsaturated fatty acids; PUFA- polyunsaturated fatty acids; UFA- unsaturated fatty acids.

\subsection{Color parameters}

The CIE Lab coordinate values $\left(\mathrm{L}^{*}, \mathrm{a}^{*}, \mathrm{~b}^{*}\right)$ of alhydwan seed oil were $65.44,1.11$ and 28.33 , respectively. These indicate the presence of yellow pigments such as carotenoid compounds. These values are close to those reported on other vegetable oils such as palm, soybean, sunflower, olive, and corn, which range from 63.4 to $69.5,3.8$ to 4.4 and 9.2 to 10.4 , respectively (Hsu and $\mathrm{Yu}, 2002$ ).

\subsection{Tocol composition}

The tocopherol and tocotrienol composition of alhydwan seed oil are shown in Table 4. The seed oil showed high amounts of $\alpha$-tocotrienol $(\alpha-\mathrm{T} 3)$, $\gamma$-tocopherol $(\gamma-\mathrm{T})$, and $\gamma$-tocotrienol $(\gamma$-T3). The major tocols were the $\alpha-\mathrm{T} 3$, which was $68 \%$ of total tocols. Fatnassi et al. (2009) reported that $\alpha$-tocopherol is useful to human nutrition due to its higher biological activity than other tocopherols. The total tocopherol content in B. elegana Choisy seed oil was $53.20 \mathrm{mg} \cdot 100 \mathrm{~g}^{-1}$ oil, which is very close to that of palm seed oil $\left(51.54 \mathrm{mg} \cdot 100 \mathrm{~g}^{-1}\right)$ reported by Nehdi et al. (2010). The results strongly suggest that the B. elegana Choisy seed oil is a rich source of $\alpha$-tocotrienol ( $\alpha$-T3), also similar to palm oil (Al-Saqer et al., 2004). It should be noted that tocopherols and tocotrienols have antioxidant properties and they are active as vitamin $\mathrm{E}$, whose deficiency affects hemolysis in humans and nervous system development in children (Mohamed et al., 2007).
TABLE 4. Tocols and sterols of alhydwan seed oil

\begin{tabular}{lc}
\hline Compound & $\mathbf{m g} \cdot \mathbf{1 0 0} \mathbf{g}^{-\mathbf{1}} \mathbf{\text { oil }}$ \\
\hline Tocols & \\
$\alpha$-Tocopherol & $0.92 \pm 0.09$ \\
$\beta$-Tocopherol & $8.22 \pm 0.13$ \\
$\gamma$-Tocopherol & $1.03 \pm 0.08$ \\
$\delta$-Tocopherol & $2.02 \pm 0.11$ \\
$\alpha$-Tocotrienol & $38.02 \pm 0.10$ \\
$\gamma$-Tocotrienol & $5.33 \pm 0.06$ \\
Total tocols & $55.54 \pm 0.09$ \\
Sterols & \\
Stigmasterol & $2.26 \pm 0.40$ \\
Campesterol & $26.24 \pm 0.70$ \\
$\Delta 7$-Avenasterol & $4.02 \pm 0.77$ \\
$\Delta 7$-Stigmastadienol & $2.66 \pm 0.10$ \\
$\Delta 5$-Avenasterol & $24.44 \pm 0.3$ \\
$\Delta 5,24-S t i g m a s t a d i e n o l$ & $14.25 \pm 0.50$ \\
$\beta$-Sitosterol & $231.11 \pm 1.02$ \\
Cholesterol & $1.92 \pm 0.3$ \\
Total sterols & 306.90
\end{tabular}

All determinations were carried out in triplicate and mean value 土standard deviation.

\subsection{Sterols}

The sterol contents of this crude oil are presented in Table 4. It was found that alhydwan seeds mainly contained $\Delta 5$-avenasterol, $\beta$-sitosterol, campesterol, $\Delta 5,24$-stigmastadienol, $\Delta 7$-stigmastenol, $\Delta 7$ avenasterol, stigmasterol and cholesterol. But the predominant one was $\beta$-sitosterol $\left(231.11 \mathrm{mg} \cdot 100 \mathrm{~g}^{-1}\right.$ oil) and is similar to palm seed oils (Nehdi et al., 2010).

\subsection{Phenolic acids}

It is well known that the phenolic compounds are minor oil constituents which play a crucial role in the flavor and on the resistance against oxidation and shelf life because of their chemical characteristics. Table 5,

TABle 5. Phenolic acids $\left(\mathrm{mg} \cdot 100 \mathrm{~g}^{-1}\right)$ composition of Alhydwan (Boerhavia elegana Choisy) seed oil

\begin{tabular}{lc}
\hline Phenolic acids Composition & Composition \\
\hline$p$-coumaric & $4.1 \pm 0.15$ \\
caffeic & $1.2 \pm 0.33$ \\
vanillic & $2.3 \pm 0.23$ \\
galic & $1.6 \pm 0.45$ \\
ascorbic & $5.44 \pm 0.11$ \\
cinnamic & $3.4 \pm 0.56$ \\
ferulic & $2.6 \pm 0.29$ \\
\hline
\end{tabular}

Values are means $\pm \mathrm{SD}$ of three determinations. 
Physicochemical properties, phenolic acids and volatile compounds of oil extracted from dry alhydwan $\bullet 7$

TABLE 6. Headspace volatile components of alhydwan seed oil, retention time and peak area percent (\%) and retention time (min)

\begin{tabular}{|c|c|c|c|}
\hline Serial & Components & $\mathbf{R t}^{*}(\min )$ & Peak area $(\%)$ \\
\hline 1 & Heptane & 3.21 & 0.05 \\
\hline 2 & Octane, 2,7-dimethyl- & 10.29 & 0.05 \\
\hline 3 & 1,6-Anhydro-á-d-talopyranose & 17.09 & 0.20 \\
\hline 4 & 1,6-Anhydro-à-d-galactofuranose & 19.22 & 0.06 \\
\hline 5 & 4-(1-Hydroperoxy-2,2-dimethyl-6-methylene-cyclohexyl)-pent-3-en-2-one & 19.51 & 0.19 \\
\hline 6 & Heptanoic acid, anhydride & 19.60 & 0.12 \\
\hline 7 & 1s,4R,7R,11R-1,3,4,7-Tetramethyltricyclo[5.3.1.0(4,11)]undec-2-en-8-one & 19.73 & 0.37 \\
\hline 8 & Dodecane, 2,7,10-trimethyl- & 20.01 & 0.11 \\
\hline 9 & Phenol, 2,4-bis(1,1-dimethylethyl)- & 20.31 & 0.12 \\
\hline 10 & Butylated Hydroxytoluene & 20.40 & 2.72 \\
\hline 11 & Dodecanoic acid & 21.33 & 0.35 \\
\hline 12 & Diethyl Phthalate & 21.95 & 0.09 \\
\hline 13 & 2,6-di-tert-Butyl-4-(dimethylaminomethyl)phenol & 23.86 & 0.15 \\
\hline 14 & Tetradecanal & 24.03 & 0.22 \\
\hline 15 & Tetradecanoic acid & 24.66 & 0.05 \\
\hline 16 & Tetradecanamide & 24.72 & 0.07 \\
\hline 17 & 3,5-di-tert-Butyl-4-hydroxybenzaldehyde & 24.84 & 0.05 \\
\hline 18 & 3,7,11,15-Tetramethyl-2-hexadecen-1-ol & 25.70 & 0.13 \\
\hline 19 & Pentadecanoic acid & 25.91 & 0.06 \\
\hline 20 & 1,2-Benzenedicarboxylic acid, bis(2-methylpropyl) ester & 26.06 & 0.11 \\
\hline 21 & Silane, trichlorooctadecyl- & 26.66 & 0.35 \\
\hline 22 & Hexadecenoic acid, Z-11- & 26.81 & 18.52 \\
\hline 23 & n-Hexadecanoic acid & 27.11 & 0.09 \\
\hline 24 & n-Hexadecanoic acid & 27.40 & 0.09 \\
\hline 25 & Z-8-Methyl-9-tetradecenoic acid & 27.79 & 0.15 \\
\hline 26 & Heptadecanoic acid & 27.97 & 0.06 \\
\hline 27 & Hexadecenenitrile & 28.19 & 0.05 \\
\hline 28 & Z-10-Pentadecen-1-ol & 28.29 & 56.73 \\
\hline 29 & 9,12-Octadecadienoic acid (Z,Z)- & 28.82 & 3.93 \\
\hline 30 & Octadecanoic acid & 28.98 & 0.43 \\
\hline 31 & 9-Octadecenamide, $(\mathrm{Z})$ - & 29.16 & 0.39 \\
\hline 32 & Acetic acid, octadecyl ester & 29.34 & 0.94 \\
\hline 33 & Pyrrolidine, 1-(1-oxo-7,10-hexadecadienyl)- & 30.55 & 0.52 \\
\hline 34 & Erucic acid & 30.84 & 0.06 \\
\hline 35 & E-8-Methyl-9-tetradecen-1-ol acetate & 30.95 & 1.04 \\
\hline 36 & 9,12-Octadecadienoic acid (Z,Z)-, 2-hydroxy-1-(hydroxymethyl)ethyl ester & 31.10 & 3.04 \\
\hline 37 & 9-Octadecenamide, $(\mathrm{Z})$ - & 31.17 & 0.07 \\
\hline 38 & Hexadecanoic acid, 1-(hydroxymethyl)-1,2-ethanediyl ester & 31.34 & 0.50 \\
\hline 39 & Tetradecanamide & 31.47 & 0.51 \\
\hline 40 & Diisooctyladipate & 31.61 & 0.17 \\
\hline 41 & 13-Tertadecen-1-ol acetate & 31.75 & 0.17 \\
\hline 42 & 1-Heneicosyl formate & 33.07 & 0.11 \\
\hline 43 & Pentacosane & 33.20 & 0.80 \\
\hline 44 & Hexadecanoic acid, 2-hydroxy-1-(hydroxymethyl)ethyl ester & 33.42 & 0.14 \\
\hline 45 & 1,2-Benzenedicarboxylic acid, diisooctyl ester & 34.22 & 0.13 \\
\hline 46 & Docosanoic acid & 34.47 & 1.34 \\
\hline 47 & 9,12-Octadecadienoic acid (Z,Z)-, 2-hydroxy-1-(hydroxymethyl)ethyl ester & 37.58 & 0.52 \\
\hline 48 & 9-Octadecenoic acid (Z)-, 2-hydroxy-1-(hydroxymethyl)ethyl ester & 37.64 & 0.05 \\
\hline
\end{tabular}

Major volatile (>2.0\%) bold; *RT: Retention times. 
shows the phenolic acids with their HPLC retention times and concentrations. In alhydwan seed oil, seven phenolic acids were identified, namely accorbic acid (the most abundant), $p$-coumaric acid, cinnamic acid, ferulic acid, vanillic acid, galic acid and caffeic acid. This is a good indication that the phenolics of this plant are important components as the Boerhavia elegana Choisy seeds possessed high phenolic content. Therefore, Alhydwan (B. elegana Choisy) seeds can be used as a good source of natural antioxidants which can have an invaluable pharmacological effect (Alfarga et al., 2014).

\subsection{Volatile compounds}

The forty-eight volatile compounds found in alhydwan seed oil are shown in Table 6. The peak area percentage was used to indicate the relative concentration of each compound. The main compounds identified based on relative contents were; Z-10Pentadecen-1-ol (56.73\%); Hexadecenoic acid, Z-11(18.52\%); 9,12-Octadecadienoic acid (Z,Z)-(3.93\%); 2-hydroxy-1-(hydroxymethyl)ethyl ester (3.04\%) and Docosanoic acid (1.34\%). Volatile compounds play a prominent role as flavoring agents in the food industry and they are responsible for a plant's distinctive scent or taste (Bruneton, 1999). Flavor volatiles are derived from an array of nutrients, including carotenoids, amino acids, and fatty acids (Goff and Harry, 2006). Alhydwan seeds oil can be considered a good source of volatile compounds, which can be used as an addition to several food or beverages to give them better taste and flavor.

\section{CONCLUSION}

The results of this study have revealed that alhydwan seed oil has a number of compounds which makes it a commendable food oil. Comparatively, it has shown some similarity with palm seed oil. The high contents of monounsaturated fatty acids, the liquid state at room temperature and the many volatile compounds present make it potentially healthy and a good organoleptic oil for human consumption. Unfortunately, many countries are not even familiar with the alhydwan plant, much less consider its potential of being a source of good oil. This study is the first carried out on the alhydwan seed grown in Yemen, opening the way for further studies on these seeds.

\section{REFERENCES}

Al-Farga A, Zhang H, Azhari S. 2014. In Vitro Antioxidant Activity and Total Phenolic and Flavonoid Contents of Alhydwan (Boerhavia elegana Choisy) Seeds. J. Food Nutr. Res. 2, 215-220.

Al-Saqer JM, Sidhu JS, Al-Hooti SN, Al-Amiri HA, Al-Othman A, Al-Haji L, Ahmed N, Mansour I, Minal J. 2004. Developing functional foods using red palm IIII olein. IV. Tocopherols and tocotrienols. Food Chem. 85, 579-583. http://dx.doi. org/10.1016/j.foodchem.2003.08.003.

American Soybean Association Soy Stats. 2007. A reference guide to important Soybean Fats and Figures.

AOAC. 2000. Official methods of analysis of AOAC International, 17th ed., Vols. 1 and 2, AOAC International, Gaitherburg, Maryland, USA Washington, DC: Association of Analytical Chemists.

AOAC. 1995. Official methods of analysis of Association of Official Analytical Chemists International. Washington, USA.

AOCS. 1997. Official Methods and Recommended Practices of the American Oil Chemists Society, 5th ed. AOCS Press, Champaign, USA

Aparicio R, Roda L, Albi MA, Gutiérrez F. 1999. Effect of various compounds on virgin olive oil stability measured by Rancimat. J. Agric. Food Chem. 47, 4150-4155. http:// dx.doi.org/10.1021/jf9812230.

Azhari S, Xu YS, Jiang QX, Xia WS. 2014. Physicochemical properties and chemical composition of Seinat (Cucumismelo var. tibish) seed oil and its antioxidant activity. Grasas Aceites, 65, 1-9. http://dx.doi.org/10.3989/gya.074913.

Besbes S, Blecker C, Deroanne C, Drira NE, Attia H. 2004. Date seeds: chemical composition and characteristic profiles of the lipid fraction. Food Chem. 84, 577-584. http://dx.doi. org/10.1016/S0308-8146(03)00281-4.

Boulous L. 1988. Contribution to the flora of South Yemen (PDRY). Candollea, 43, 549-585.

Bowen RAR, Clandinin MT. 2005. Maternal dietary 22:6n-3 is more effective than 18:3n-3 in increasing the 22:6n-3content in phospholipids of glial cells from neonatal rat brain. Brit. $J$. Nutr. 93, 601-611. http://dx.doi.org/10.1079/BJN20041390.

Bruneton J, 1999. Pharmacognosy, Phytochemistry, Medicinal Plants: Essential Oils, 2nd ed. Lavoisier Publishing, New York, pp. 461-780.

Chaudhary G, Dantu PK. 2011. Morphological, phytochemical and pharmacological, studies on Boerhavia diffusa L. J. Med. Plants Res. 5, 2125-2130.

da Silva Araújo F, Araújo IC, Costa ICG, Rodarte de Moura CV, Chaves MH, Araújo ECE. 2014. Study of degumming process and evaluation of oxidative stability of methyl and ethyl biodiesel of Jatropha curcas $L$. oil from three different Brazilian states. Renewable Energy 71, 495-501. http:// dx.doi.org/10.1016/j.renene.2014.06.001

Duyff RL, Ada AF. 2011. American dietetic association complete food and nutrition guide: Houghton Mifflin Harcourt.

El-Mallah MH, Mumi T, El-Shami S. 1999. New trends in determining the authenticity of corn oil. Grasas Aceites 50, 7-15. http://dx.doi.org/10.3989/gya.1999.v50.i1.629.

Eromosele IC, Eromosele CO, Innazo P, Njerim P. 1997. Studies on some seeds and seed oils. Bioresour. Technol. 64, 245-247. http://dx.doi.org/10.1016/S0960-8524(97)00163-6.

Fatnassi S, Nehdi I, Zarrouk H. 2009. Chemical composition and profile characteristics of Osage orange Maclurapomifera (Rafin.) Schneider seed and seed oil. Ind. Crops Prod. 29, 1-8. http://dx.doi.org/10.1016/j.indcrop.2008.04.013.

Goff SA, Klee HJ. 2006. Plant volatile compounds: sensory cues for health and nutritional value? Science, 311, 815-819. http://dx.doi.org/10.1126/science.1112614.

Hsu SY, Yu SH. 2002. Comparisons on 11 plant oil fat substitutes for low-fat kung-wans. J. Food Eng. 51, 215-220. http://dx.doi.org/10.1016/S0260-8774(01)00059-0.

ISO/FIDS 12228. 1999. International Standards, 1 st ed. Genève, Switzerland.

Jelassi A, Cheraief I, Jannet HB. 2014. Chemical composition and characteristic profiles of seed oils from three Tunisian Acacia species. J. Food Comp. Anal. 33, 49-54. http:// dx.doi.org/10.1016/j.jfca.2013.11.001

Kyriakidis NB, Katsiloulis T. 2000. Calculation of iodine value from measurements of fatty acid methyl esters of some oils: comparison with the relevant American Oil Chemists Society Method. J. Am. Oil Chem. Soc. 77, 1235-1238. http://dx.doi.org/10.1007/s11746-000-0193-3.

Mohamed R, Fernandez J, Pineda M, Aguilar M. 2007. Roselle (Hibiscus sabdariffa) seed oil is a rich source of 
tocopherol. J. Food Sci. 72, S207-S211. http://dx.doi. org/10.1111/j.1750-3841.2007.00285.x.

Mulatu G, Sten S, Thomas B. 2011. Variation and inheritance of oil content and fatty acid composition in niger (Guizotiaabyssinica). J. Food Comps. Anal. 24, 995-1003. http://dx.doi.org/10.1016/j.jfca.2010.12.010.

Nehdi I, Omri S, Khalil MI, Al-Resayes SI. 2010. Characteristics and chemical composition of date palm (Phoenix canariensis) seeds and seed oil. Indus. Crops. Prod. 32, 360-365. http://dx.doi.org/10.1016/j.indcrop.2010.05.016.

Nyam KL, Tan CP, Lai OM, Long K, Mana CYB. 2009. Physicochemical properties and bioactive compounds of selected seed oils. Food Sci. Biotechnol. 42, 1396-1403. http://dx.doi.org/10.1016/j.lwt.2009.03.006.

Nyam KL, Tan CP, Lai OM, Long YB, Che M. 2009. Physicochemical properties and bioactive compounds of selected seed oils. LWT-Food Sci. Technol. 42, 1396-1403.

Ojeh O. 1981. Effects of refining on the physical and chemical properties of cashew kernel oil. J. Fats Oils Technol. 16, 513-517.

Oomah BD, Ladet S, Godfrey DV, Liang J, Girard B. 2000. Characteristics of raspberry (Rubusidaeus L.) seed oil. Food Chem. 69, 187-193. http://dx.doi.org/10.1016/S03088146(99)00260-5.
Osborne DR, Voogt P. 1978. Calculation of Caloric Value. In: "Analysis of Nutrients in Foods". Academic Press, New York, pp. 23-34.

Ranganna S. 1986. Handbook of analysis and quality control for fruit and vegetable products. New Delhi: Tata $\mathrm{Me}$ Graw-Hill Publishing Company. 1112 pp.

Saidu AN, Jideobi NG. 2009. The proximate and elemental analysis of some leafy vegetables grown in Minna and Environs. J. Appl. Sci. Envir. Manage 13, 21-22.

Sbihi HM, Nehdi IA, Tan CP, Al-Resayes SI. 2013. Bitter and sweet lupin (Lupinus albus L.) seeds and seed oils: A comparison study of their compositions and physicochemical properties. Indus. Crops Prod. 49, 573-579. http://dx.doi. org/10.1016/j.indcrop.2013.05.020.

$\mathrm{Su}$ MH, Shih MC, Lin KH. 2014. Chemical composition of seed oils in native Taiwanese Camellia species. Food Chem. 156, 369-373. http://dx.doi.org/10.1016/j.foodchem.2014. 02.016.

Tan CP, Che Man YB, Selamat J, Yusoff MSA. 2002. Comparative studies of oxidative stability of edible oils by differential scanning calorimetry and oxidative stability index methods. Food Chem. 76, 385-389. http://dx.doi. org/10.1016/S0308-8146(01)00272-2. 